\title{
The Ecotoxicology of Heavy Metals from Various Anthropogenic Sources and Pathways for their Bioremediation
}

\author{
ANDREI CRISTIAN GRADINARU, GHEORGHE SOLCAN, MIHALEA CLAUDIA SPATARU*, LUMINITA DIANA HRITCU*, \\ LIVIU CATALIN BURTAN, CONSTANTIN SPATARU \\ Ion Ionescu de la Brad University of Agricultural Sciences and Veterinary Medicine of laㅇ, Faculty of Veterinary Medicine, \\ 8 Sadoveanu Alley, 700490, Iasi, Romania
}

\begin{abstract}
Although $\mathrm{Cu}$ and $\mathrm{Zn}$ are important microelements with well-defined roles in organisms functioning, their presence in toxic concentrations is related to a contamination process. On the other hand, $\mathrm{Pb}, \mathrm{Cd}$, and $\mathrm{Hg}$ are toxic xenobiotics with cumulative effects on various organisms, and in the case of Ni the reports are contradictory. All of these heavy metals are found as a naturally content in the earth's crust wherefrom are mobilized through volcanic eruptions or mining activities. Some human activities, such as metals smelting, burning of fossil fuels, cement obtaining, usage of pesticides in agriculture, contribute to the environmental pollution with these heavy metals. The presence of heavy metals is considered a risk factor for all components of the ecosystem due to their geo- and bio accumulative features. In long-term exposure, especially in countries with intensive industrialization and urbanization, toxic and carcinogenic effects based on various mechanisms were reported. However, the extraction and the usage of heavy metals in various industry branches might be considered a necessary evil for the nowadays modern society. In some moments of our evolution there were no alternatives, neither as knowledge, nor as application possibilities. In last decades, alarm signals were pulled by the scientific community and non-governmental organizations, and a legislation of heavy metal residues monitoring was developed and applied in many countries all over the world. Moreover, various ecological alternatives were found for the limitation or even excluding of pollutant materials from many of our life aspects (unleaded petrol, insecticides based on pheromones, green concrete manufactured with less cement quantity etc.) and different ways of soil phytoremediation and heavy metals biosorption from aqueous media were tested. The aim of this paper is to review the most important aspects related to heavymetals ( $\mathrm{Pb}, \mathrm{Cd}, \mathrm{Hg}, \mathrm{Ni}, \mathrm{Cu}, \mathrm{Zn}$ ) ecotoxicology. Various sources of environmental pollution and different mechanisms for physiological homeostasis disruption for each reviewed elementary xenobiotic are critically discussed.
\end{abstract}

Keywords: bioaccumulation, bioremediation, heavy metals, persistence

The pollution with heavy metals is a risk factor on the quality of life, being mostly based on human activities related to mining, burning of fossil fuels, pesticides using, production of batteries, smelting of metals etc. [1]. The effects of heavy metals pollution are different among organism types, and between various species. The consequences are difficult to be established on a short term, being affected not just the elements from the base of the ecosystem, butalso the superior organisms. Humans and animals are on the risk due to various ways of contamination, most commonly respiratory and digestive. By affecting the food chain, the contamination with heavy metals poses a threat to the safety and security of the consumer, significant on the long-term. The defining of heavy metals was a special concern of specialists up to now, in most of the cases being tried analogies with their density higher than $5 \mathrm{~g} / \mathrm{cm}^{3}$. However, various controversies in this regard occurred, different lower limits being established at $7 \mathrm{~g} / \mathrm{cm}^{3}, 4 \mathrm{~g} / \mathrm{cm}^{3}, 4.5 \mathrm{~g} / \mathrm{cm}^{3}$ or $3.5 \mathrm{~g} / \mathrm{cm}^{3}$ [2]. Although several of heavy metals ( $\mathrm{Co}, \mathrm{Cu}, \mathrm{Fe}, \mathrm{Mn}, \mathrm{Mo}$, Se, $\mathrm{Ni}$ and $\mathrm{Zn}$ ) are considered micronutrients for plants and animals [3], some ( $\mathrm{As}, \mathrm{Cd}, \mathrm{Cr}, \mathrm{Pb}$ and $\mathrm{Hg}$ ) are potentially toxic even at low doses [4].

The aim of this paper is to review the most important aspects related to heavy metals ( $\mathrm{Pb}, \mathrm{Cd}, \mathrm{Hg}, \mathrm{Ni}, \mathrm{Cu}$ and $\mathrm{Zn}$ ) ecotoxicology, considering the pollution with heavy metals one of the most significant in terms of its cumulative, mutagenic and carcinogenic effects on the living organisms.
Chemical characterization and sources of $\mathrm{Pb}, \mathrm{Cd}, \mathrm{Hg}$, $\mathrm{Ni}, \mathrm{Cu}$, and $\mathrm{Zn}$ contamination

Although heavy metals ( $\mathrm{Pb}, \mathrm{Cd}, \mathrm{Hg}, \mathrm{Ni}, \mathrm{Cu}$ and $\mathrm{Zn}$ ) are elementary xenobiotics, naturally found in the earth's crust, most of the environmental contamination is based on human activities [4]. Heavy metals are bio accumulative because, unlike organic pollutants, they cannot be biodegraded. They persist and cause pollution of the environment, being a risk factor for all living organisms [58].

Lead $(P b)$ is a heavymetal $\left(11.34 \mathrm{~g} / \mathrm{cm}^{3}\right)$ whose sources and effects on living organisms were well-documented during last years. Nowadays, its ore source of extraction is the natural sulfide, galena ( $P b S$ ) or its oxidation product, ceruse $\left(\mathrm{PbCO}_{3}\right)$ [9]. Mining activities, lead smelters, burning of fossil fuels, or production of batteries are the mostimportant sources of environment contamination with $P b$ [1]. In addition, several sources were related in the past decades with animal or human organism contamination: lead containing paints (consumed by ruminants), water transport pipes made of lead alloys, exhaust gas emitted by engines which used high octane fuel. In 2014, Kessler (2014) [10] reported an interesting case of pica syndrome in humans. It was as a consequence of huge patches of pale lemon-yellow paint consuming from the walls by a student, the level of $P b$ in its blood being found at $52 \mu \mathrm{g} / \mathrm{dL}$, far above the concentration of $5 \mu \mathrm{g} / \mathrm{dL}$, at which the intervention is recommended. In the matter of leaded petrol combustion, nowadays is not a significant risk for lead 
pollution due to a w orldwide restriction in use for this type of fuel. However, according to a Who study reviewed by [11], at the end of 1980's the combustion of leaded petrol contributed with $80-90 \%$ of air lead pollution.

Cadmium $(C d)$ is a heavy metal $\left(8.65 \mathrm{~g} / \mathrm{cm}^{3}\right)$ naturally found in zinc ores: $5 \mathrm{wt} \% \mathrm{Cd}$ in sphalerite or zinc blende $[(\mathrm{Zn}, \mathrm{Fe}) \mathrm{S}]$, and $4.5 \mathrm{wt} \% \mathrm{Cd}$ in smithsonite or zinc carbonate $\left(\mathrm{ZnCO}_{3}\right)$ [12]. The largest emissions of atmospheric cadmium are due to the steel industry and waste incineration, followed by volcanic action and zinc production $[4,13]$. Large amounts of $C d$, as well as $P b$ and $\mathrm{Hg}$ found in nature, may be attributed to various activities in the construction industry such as those related to cement obtaining in which particles of dust are released in atmosphere and carried by the wind in neighboring regions. The process of cement obtaining is energy consuming requiring coal burning. The resulted combustion gases contain particles of heavy metals and also represent an important source in this regard $[14,15]$. However, the coal combustion is not a process found only in the cement industry; the power plants are based on coal burning and any other industrial activity, which involves this process, is a presumed source of pollution with various heavy metals.

Mercury $(\mathrm{Hg})$ is a naturally occurring element $(13.59 \mathrm{~g} /$ $\mathrm{cm}^{3}$ ), directly mobilized by humans through mining activities. Cinnabar, (HgS) is the primary mineralogical source of mercury which forms a bright red pigment, vermillion, when powdered, being used in the process of precious metals extraction $(A u, A g)$, in the manufacturing of various products such as chlorine-alkali paints, electronic devices or various instruments used in physics and medicine [16-18]. Mercury is a volatile heavy metal, being found in atmosphere especially in volcanic areas [18]. The use of various fertilizers in agriculture with the aim of an adequate $N, P$, and $K$ providing for crop growth, usually adds contaminants such as $\mathrm{Hg}, \mathrm{Pb}$, and $\mathrm{Cd}$, which are potentially toxic to the soil, plants, and animals and humans which consume the obtained vegetables [19-21].

Nickel (Ni) is naturally found in various forms, such as nickeline (NiAs), millerite (NiS), pentlandite [(Ni, Fe)S]. It is a heavy metal $\left(8.9 \mathrm{~g} / \mathrm{cm}^{3}\right)$ that contaminates the environment as a result of mining process, volcanic eruptions, or from the melting of stainless steel (at whose manufacture $\mathrm{Ni}$ is used). Nickel-cadmium batteries are one of the most important sources of pollution in their wastes sites [22].

Copper $(\mathrm{Cu})$ is usually found in natural combinations, especially as sulfides [chalcopyrite (CuFeS,), chalcocite $(C u, S)$, covellite (CuS)]. It is a heavy metal $\left(9 \mathrm{~g} / \mathrm{cm}^{3}\right)$ used in electronics, metallurgic industry, agriculture (fertilizers, pesticides containing $\mathrm{Cu}$ ), animal husbandry (as a feed additive) or in food industry (containers, pipes) [23].

Zinc $(Z n)$ is a heavy metal $\left(7.14 \mathrm{~g} / \mathrm{cm}^{3}\right)$ naturally occurring as sphalerite (zinc blende) and smithsonite (zinc carbonate) [12]. The environmental $Z n$ pollution is related to mining activities, coal combustion, steel processing. Water and foods are usually Zn enriched if they are stored in metal ( $Z n$ containing) tanks [19].

\section{Mechanisms of $\mathrm{Pb}, \mathrm{Cd}, \mathrm{Hg}, \mathrm{Ni}, \mathrm{Cu}$, and $\mathrm{Zn}$ toxicity in humans and animals}

The effects of heavy metal residues on human and animal organisms depend on the amount of toxic taken up, the way of entering and absorption in the body, its elimination and accumulation in specific organs. A part of ingested heavy metals can be eliminated through feces, and another part is absorbed in blood stream and redistributed to specific organs of storage: liver, kidneys, bones, nervous system, and in a lesser degree in lungs or spleen. It is well known that once absorbed, heavy metals are bound to erythrocytes membrane, to hemoglobin in erythrocytes ( $P b$, for example) or via erythrocytes or albumin proteins ( $C d$, for example) [24-26].

There is a selective distribution of metal ions in organs and tissues, depending on their affinity. For example, Cheng et al. (2001) [27] reported Pb in high concentrations in bones, up to $95 \%$ from the total body lead burden in adults accumulating in skeleton, which interchanges with lead from the blood and soft tissues. In the same report, the bone lead levels were positively associated with the incidence of hypertension in men volunteers. In a study of preferential accumulation of heavy metals in different tissues of rats following respiratory exposures, $\mathrm{Li}$ et al. (2015) [28] reported increased levels of $P b$ in the liver, lung, and cerebral cortex and of $\mathrm{Cu}$ in the liver. Among reviewed heavy metals, $C d$ and Ni showed no difference between the control group and the three groups of rats exposed to the atmospheric pollutants. Jakimska et al. (2011) [29] reported that the liver is the first response organ at toxic $C d$ concentrations. However, this organ is usually affected in various toxic aggressions due to its role in detoxification. Although female birds are capable of excreting metals from the organisms via feathers or eggs, only small amounts of $C d$ and $P b$ were reported to be eliminated by the eggs, almost all the $C d$ concentrations being retained in the system. Among reviewed heavy metals, $\mathrm{Hg}, \mathrm{Cu}$ and $\mathrm{Pb}$ were reported to accumulate in the feathers [29].

The effects of heavy metals on human and animal organisms involve specific mechanisms for each of them. Some of xenobiotics $(C d, P b$ and $\mathrm{Hg})$ disrupt the functional mechanisms by replacing physiological metals $(\mathrm{Cu}, \mathrm{Zn}$ and Ca) [29]. Due to their affinity in special for sulfhydryl groups $(-\mathrm{SH})$ found in proteins and enzymes, it is well-known the heavy metals ability to bind these kind of molecules and to alter their activity [24, 30]. However, there are various mechanisms of action for reviewed xenobiotics related to well-known clinical symptoms. Lead ions $\left(\mathrm{Pb}^{2+}\right)$, for example, are capable to interfere with $\mathrm{Ca}^{2+}$ ions due to some of their similarities. As a result, the access of calcium at the synaptic levels is limited, reducing the signal transduction [31]. Lead is also shown to inhibit the synthesis of hemoglobin, inactivating the deltaAminolevulinic Acid Dehydratase (ALAD or porphobilinogen synthase), an enzyme which catalyses the conversion of two molecules of delta -Aminolevulinic Acid $(A L A)$ in one molecule of porphobilinogen. As a result, the ALA concentration in blood will increase, and also of $\mathrm{Fe}^{2+}$ due to the lead inhibition of ferrochelatase enzyme responsible for protopophyrin IX and $\mathrm{Fe}^{2+}$ joining for hem synthesis. This affecting of hem synthesis lead to anemia; the same effect is obtained due to lead induced changes in the composition of proteins and lipids located in the membrane of red blood cells, increasing their fragility and decreasing their average life span (intravascular hemolysis) [24]. As a primary toxic effect, cadmium ions $\left(\mathrm{Cd}^{2+}\right)$ inhibit the $\mathrm{Ca}^{2+}$ transporting enzymes, disturbing cellular $\mathrm{Ca}^{2+}$ metabolism [32]. However, $C d$ is a well-known thiol reagent, its main mechanism of toxicity being represented by essential thiol groups (-SH) binding in the cysteine-containing enzymes with mercaptide complexes formation. Another mechanism of $C d$ enzymes inhibition is that of essential metal cofactors (such as $Z n$ ) replacing. There are various studies on different enzymes inactivated by $\mathrm{Cd}$, some of them reffering to superoxide dismutase, catalase, succinate dehydrogenase, glutathione related enzymes, 
delta -ALA dehydrase [33-35]. The inhibitory effect of $C d$ on delta -ALA dehydrase is not singular, the same effect being already mentioned for $\mathrm{Pb}$, and also reported for $\mathrm{Hg}$, $\mathrm{Zn}$ and $\mathrm{Cu}[35,36]$. Considering the role of sulfhydryl groups of membrane proteins in electrical conduction and chemical transmission processes, the electrical excitability and synaptic transmission are affected by heavy metals binding at these groups [37]. Proteins participating in the DNA repair systems are also targets of $C d$ toxicity. Therefore, $C d$ is considered one of the main heavy metals with carcinogen potential due to its inhibitory effects on DNA repair activities [38, 39]. Besides sulfhydryl, phosphoryl, carboxyl, amide and amine groups binding, and toxic effects by protein precipitation and enzyme inhibition [40], the inorganic $\mathrm{Hg}^{2+}$ is able to be converted to its organic form, methyl mercury (by the action microorganisms), the resulted compound being very stable, with cumulative effect, especially in aquatic organisms. It represents a dietary risk for the consumers, having a well-known neurotoxic effect. The phenomenon of biological methylation is also known for $P b$ and $A s$ [41, 42]. Neurotoxic and carcinogenic properties were also reported for $\mathrm{Ni}$ ions. They are usually bound to sulfhydryl groups of proteins and, as other reviewed heavy metals $(\mathrm{Pb}, \mathrm{Cd}, \mathrm{Hg}$ and $\mathrm{Cu})$, are oxidative stress inductors, with metabolic damages (lipids peroxidation, proteins dysfunction) and at the DNA level [43, 44]. As previously mentioned, the mechanism of Cu toxicity is related to sulfhydryl groups binding and subsequent enzymes inactivation (glucose-6-phosphate dehydrogenase, glutathione reductase). Hemolysis was reported as an important effect of $\mathrm{Cu}$ intoxication, being caused either by a direct red cell membrane damage (the cell membrane integrity is affected by protein sulfhydryl groups binding and oxidative degradation of constituents lipids) or as a result of enzymes inactivation (with functions of protection against oxidative stress). The methemoglobin formation is of a particular significance in $\mathrm{Cu}$ intoxications, the oxidation of hem iron leading to the reduction of blood oxygen carrying capacity [45]. Comparing to other reviewed heavy metals, $\mathrm{Zn}$ is considered relatively harmless. At high doses and for a long time of exposure, there was reported to interfering with $\mathrm{Cu}$ uptake, which lead to effects associated with $\mathrm{Cu}$ deficiency: hypocupremia, impaired iron immobilization, anemia, leukopenia, neutropenia, decreased amounts of copper dependent enzymes, such as superoxide dismutase, ceruloplasmin, cytochrome-c oxidase, increased levels of plasma cholesterol and LDL, HDL cholesterol, and abnormal cardiac function. Soluble zinc salts, such as zinc chloride, are generally caustic [46].

\section{Heavy metals in different elements of the ecosystem and bioremediation pathways}

The importance of heavy metals pollution comes from the fact that it affects all the components of the ecosystem: air, soil, water, and the health of living organisms. Their circuit in nature, and subsequently, the possibility of their maintaining at risk levels for many generations, is due to the connections among soil, plants, animals and humans. However, various studies reported ways of phytoremediation for contaminated soils, limiting the presence of heavy metals residues in superior organisms. This limitation is important taking into account that the contamination of animals with heavy metals is significant in high polluted areas. For example, $\mathrm{Cd}$ was found in liver at 10 fold higher concentrations than the Maximum Residue Limits (MRL) ${ }^{* *}$ and up to 30 fold higher in kidneys. Milk samples collected from the same areas and analyzed for $P b, C d$, and $Z n$ contents showed contamination of $66 \%$ of samples for $P b, 100 \%$ for $C d$, and $22 \%$ for $Z n$, at levels that exceeded 15-20 fold the MRL ${ }^{*}$ [47]. In a previous study were reported concentrations of $0.56 \mathrm{ppm}$ for $P b, 0.09 \mathrm{ppm}$ for $C d$, and $28.16 \mathrm{ppm}$ for $Z n$, well above the MRL* of $0.2 \mathrm{ppm}$, $0.01 \mathrm{ppm}$, and $5 \mathrm{ppm}$, respectively [48]. Other authors reported that the average $Z n$ concentration in liver and kidney samples collected from cattle raised within a range of 2 up to $6 \mathrm{~km}$ around a chemical plant, exceeding the MRL* about two times. In kidney and liver samples collected from sheep raised in the same areas, and also in sheep and cattle spleen samples, $Z n$ did not exceeded the MRL* at any of the control sites [49].

The mobility of heavy metals in soil depends mainly on $\mathrm{pH}$ and the amount of organic matter. As the binding of heavy metal is stronger to the organic matter of the soil, the more immobile in the soil it will become but with the possibility of being picked up easier by the plants. This is a reported behavior for $C d$ [50], $C u$ [51], $P b$ [52], and $Z n$ [53]. Generally, the presence of heavy metals in soil affects the plants growing and the content of plants dry matter, decreasing it $[54,55]$. The order of toxicity of some of the reviewed heavy metals was reported for plants by [54] as the following one: $\mathrm{Cd}>\mathrm{Hg}>\mathrm{Pb}$. Considering the effect of heavy metals up took by plants through contaminated soils on dry matter yields decreasing, Wang et al (2002) [54] established the following order: field pea, wheat, fodder vetch, rapeseed, and maize. The accumulation of heavy metals in plant tissues depends on various factors, such as: plant species, the vegetative organ, the plant age, the pH of soil. Wang et al (2002) [54] reported that field pea, fodder vetch, and wheat were more susceptible to soil metals accumulation ( $\mathrm{Cd}, \mathrm{Zn}, \mathrm{Pb}$ and $\mathrm{Cu}$ ) than were rapeseed and maize. Among the crops, maize was the highest accumulator for $\mathrm{Zn}$, and $\mathrm{Cd}$, fodder vetch for $\mathrm{Cu}$, and wheat for $\mathrm{Pb}$. In an experiment performed in contaminated soil due to a former waste incineration plant, Kacálková et al. (2014) [55] reported that $\mathrm{Ni}$ and $\mathrm{Pb}$ accumulated in highest amounts in plant roots, higher in herbs (maize, sunflower) than in trees (willow, poplar). $C d$ showed a different pattern of accumulation, highest in roots of willow, followed by the leaves of willow. Wang et al (2002) [54] reported a more Cd and Cu accumulation in the grain of wheat than of maize, suggesting safer the growing of maize as a phytoremediation of lightly contaminated soils due to its tendency to accumulate less heavy metal residues than other plants. The idea of maize using as phytoremediation is also supported by $[56,57]$. On sites with multiple metal contamination, Wang et al (2002) [54] consider safer the growing of maize and rapeseed than wheat or legumes. Lu et al (2015) [57] reported that $P b$ and Nimainlyaccumulated in maize roots, but $Z n$ in the maize seeds. The same tendency of $P b$ accumulation in higher amounts in maize roots, and smaller in seeds was also reported by [58,59]. Considering the reviewed heavy metals, their concentration in maize increased in the following order: $\mathrm{Zn}>\mathrm{Ni}>\mathrm{Pb}$ [58]. Considering the age of plants, it seems that roots of young ones display greater ability to absorb ions than old plants when they are with similar size [60]. Hough et al (2003) [60] reported for $C d$ uptake a greater dependence on soil $\mathrm{pH}$ in the case of wheat, comparing to maize. The aforementioned authors suggested that limiting the soil $\mathrm{pH}$ to 7.0 , it will reduce the $\mathrm{Cd}$ concentrations in wheat grain.

Lately, a number of studies which involve the process of biosorption become increasingly significant [61-66]. This 
process is an alternative to the more expensive electrochemical, chemical precipitation, coagulation or flocculation methods for heavy metal ions removal from aqueous media [64-66]. Utilization of various biological materials, such as different types of algae (Ulva sp., for example), agricultural waste and by-products (rape or grain biomass, rice or soy husks, sawdust, mustard waste), in an eco-friendly and cost-effective alternative for Zn(II), $\mathrm{Hg}(\mathrm{II}), \mathrm{Pb}(\mathrm{II})$ and $\mathrm{Cd}(\mathrm{II})$ ions absorption from aqueous media was tried [20, 21, 63-66]. Furthermore, the essential microelements, such as $Z n$, which was retained by ionexchange interactions, could be released in tested soils up to a saturation level is obtained [65]. An interesting process of phytoremediation was described in a microbe-plant symbiosis relationship (plant-growth-promoting rhizobacteria on radish plants for Ni phytoextraction enhancement) [62].

\section{Conclusions}

Copperand zinc are important microelements for human and animal organism, considering the role of copper in hematopoiesis and those of zinc as a component of various metalloenzymes involved in the synthesis of proteins and nucleic acids. The other heavy metals reviewed in this study are important as toxic xenobiotics, their presence in the organisms being a consequence of environmental pollution.

The presence of heavy metals in nature and their risks to organisms are constantly monitored by competent institutions. Based on toxicological studies, the J oint FAO/ WHO Expert Committee on Food Additives establishes safety indicators of residue levels to which the consumer maybe exposed (for example, Provisional Tolerable Weekly Intake, Acceptable Daily Intake). Moreover, various countries use normative acts in which Maximum Residue Limits are provided for some heavy metals in different foodstuffs, the others which are not set being considered with zero tolerance. However, such efforts must always be supported by people's concern for the protection of the environment.

\section{References}

1.CHIBUIKE, G.U., OBIORA, S.C., Applied and Environmental Soil Science, 2014, Article ID: 752708, 2014, doi: 10.1155/2014/752708. 2.DUFFUS, J.H., Pure Appl Chem,74, no. 5, 2002, p. 793.

3.ALLOWAY, B.J., Heavy metals in soils. Environmental Pollution, 22, 2013, p.195-209, doi: 10.1007/978-94-007-4470-7 7.

4.TCHOUNW OU, P.B., YEDJ OU, C.G., PATLOLLĀ, A.K., SUTTON, D.J ., Exp Suppl, 101, 2012, p. 133, doi: 10.1007/978-3-7643-8340-4_6.

5.MOHAMMED, A.S., KAPRI, A., GOEL, R., Biomanagement of MetalContamined Soils, 20, 2011, p.1, doi: 10.1007/978-94-007-1914-9.

6.MUSCALU, O.M., NEDEFF, V., SANDU, I.G., PARTAL, E., MOSNEGUTU, E., BARSAN, N., SANDU, I., RUSU, D., Rev. Chim. (Bucharest), 70, no. 5, 2019, p. 1726.

7.PAPADATU, C.P., BORDEI, M., ROMANESCU, G., SANDU, I., Rev. Chim. (Bucharest), 67, no. 9, 2016, p. 1728.

8.MUSCALU, O.M., NEDEFF, V., CHITIMUS, A.D., SANDU, I.G., PARTAL, E., MOSNEGUTU, E., SANDU, I., RUSU, D.I., Rev. Chim. (Bucharest), 69, no. 11, 2018, p. 4006.

9.STOS-GALE, Z.A., GALE, N.H., Revue d'Archéométrie, 1, 1981, p. 285.

10.KESSLER, R., Environ. Health Perspect., 122, no. 4, 2014, p. A96, doi: 10.1289/ehp.122-A96.

11.BLANUSA, M., Environ. Manag. Health, 7, no. 4, 1986, p. 23, doi: 10.1108/09566169610123069.

12.SCHWARTZ, M.O., International Geology Review, 42, no. 5, 2000, p. 445 , doi: 10.1080/00206810009465091.
13.HUTTON, M., Ecotoxicol Environ Safety, 7, no. 1, 1983, p. 9, doi.org/ 10.1016/0147-6513(83)90044-1.

14.OLUSEYE OGUNKUNLE, C., OJ O FATOBA, P., Atmos Pollut Res, 5, no.2, 2014, p. 270, doi: 10.5094/APR.2014.033.

15.ESTIFANOS, S., DEGEFA, A., International J ournal of Economic and Environmental Geology, 3, no. 2, 2012, p. 12.

16. DRISCOLL, C.T., MASON, R.P., CHAN, H.M., JACOB, D.J ., PIRRONE, N., Environ. Sci. Technol., 47, no.10, 2013, p. 4967, doi: 10.1021/ es305071v.

17. COOKE, C.A., BALCOM, P.H., BIESTER, H., WOLFE, A.P., Proc. Natl. Acad. Sci., USA, 106, no. 22, 2009, p. 8830, doi: 10.1073/ pnas.0900517106.

18. WITT, L.I., PYLE, M.., MATHER, D.M., AIUPPA, T.A., BAGNATO, E., MARTIN, R.S., The $1^{\text {th }}$ ICHMET, Poland, 2010, p.924-928.

19. WUANA, R.A., OKIEIMEN, F.E., ISRN Ecology, 2011, Article ID 402647, doi: 10.5402/2011/402647.

20. IACOBAN, C., RISCA, I.M., ROIBU, C., CIORNEA, E.T., NECULA, R., ILIEVA, D., SANDU, I., DROCHIOIU, G., Rev. Chim. (Bucharest), 70, no. 3, 2019, p. 753.

21.BODESCU, D., UNGUREANU, G., MORARU, R.A., SANDU, I.G., BEJ INARIU, C., Rev. Chim. (Bucharest), 69, no. 8, 2018, p. 2150.

22.YU, M.H., TSUNODA, H., TSUNODA, M., Environmental toxicology, Biological and health effects of pollutants, 3rd edition, CRC Press, Taylor \& Francis Group, 2011, pp. 222-223.

23.KABATA-PENDIAS, A., MUKHERJ EE, A.B., Trace Elements from Soil to Human, Springer, 2007, p. 259, https://doi.org/10.1007/978-3-540-327141.

24.SHARMA, B., SINGH, S., SIDDIQI, N.J ., Bio. Med. Res. Int., 2014, Article ID:640754, doi: 10.1155/2014/640754.

25.SOLENKVA, N.V., NEWMAN, J.D., BERGER, J.S., THURSTON, G., HOCHMAN, J.S., LAMAS, G.A., Am. Heart J., 168, no. 6, 2014, p. 812, doi: 10.1016/j.ahj.2014.07.007.

26.MRUGESH, T., DIPA, L., MANISHIKA, G., Acta Pol Pharm, 68, no.5, 2011, p. 653.

27.CHENG, Y., SCHWARTZ, J., SPARROW, D., ARO, A., WEISS, S.T., HU, H., Am. J. Epidemiol, 153, no. 2, 2001, p. 164, doi: 10.1093/aje/153.2.164. 28.LI, Q., LIU, H., ALATTAR, M., JIANG, S., HAN, J., MA, Y., JIANG, C., Scientific Reports, 5, 2015, p. 16936, doi: 10.1038/srep16936.

29.J AKIMSKA, A., KONIECZKA, P., SKORA, K., NAMIESNIK, J., Pol. J. Environ. Stud., 20, no.5, 2011, p.1117.

30.J AN, A.T., AZAM, M., SIDDIQUI, K., ALI, A., CHOI, I., HAQ, Q.M.R., Int. J. Mol. Sci., 16, no.12, 2015, p. 29592, doi: 10.3390/ijms161226183. 31.FLOREA, A.M., TABAN, J., VARGHESE, E., ALOST, B.T., MORENO, S., BUSSELBERG, D., Journal of Local and Global Health Science, 4, 2013, doi:10.5339/jlghs.2013.4.

32.VERBOST, P.M., FLIK, G., LOCK., R.A.C., WENDELAAR BONGA, S.E., J. Membr. Biol., 102, no.2, 1988, p. 97.

33.KORSLOOT, A., VAN GESTEL, C.A.M., VAN STRAALEN, N.M., Environmental Stress and Cellular Response in Arthropods, CRC Press, 2004, p. 86.

34.J AY, D., ZAMORANO, R., MUNOZ, E., GLEASON, R., BOLDU, J.L., J. Bioenerg. Biomembr., 23, no. 2, 1991, p. 381.

35.WADA, O., ONO, T., MARU, R., TOYOKAWA, K., Industrial Health, 10, no.1, 1972, p.11, doi: 10.2486/indhealth.10.11.

36.THOMPSON, J., JONES, D.D., BEASLEY, W.H., Br. J. Ind. Med., 34, no. 1, 1977, p. 32, doi: 10.1136/oem.34.1.32.

37.ZUAZAGA, C., STEINACKER, A., DEL CASTILLO, J., Puerto Rico Health Sciences J ournal, 3, no. 3, 1984, p. 125.

38.GIAGINIS, C., GATZIDOU, E., THEOCHARIS, S., Toxicol. Appl. Pharmacol., 213, no. 3, 2006, p. 282, doi: 10.1016/j.taap.2006.03.008.

39.LUTZEN , A., LIBERTI, S.E., RASMUSSEN, L.J., Biochem. Biophys. Res. Commun., 321, no. 1, 2004, p. 21, doi: 10.1016/j.bbrc.2004.06.102. 40.BROUSSARD, L.A., HAMMETT-STABLER, C.A., WINECKER, R.E., ROPERO-MILLER, J.D., Laboratory Medicine, 33, no. 8, 2002, p. 614, doi: 10.1309/5HY1-V3NE-2LFL-P9MT.

41.GADD, G.M., Microbiology SGM, 156, 2010, p. 609, doi: 10.1099/ mic.0.037143-0. 
42.HAMDY, M.K., NOYES, O.R., Applied Microbiology, 30, no. 3,1975, p. 424.

43.MIELCARZ, L., SMOLINSKA, B., Biotechnol Food Sci, 80, no. 1, 2016, p. 43.

44.ERCAL, N., GURER-ORHAN, H., AYKIN-BURNS, N., Curr. Top. Med. Chem., 1, no. 6, 2001, p. 529.

45. SARAVU, K., JOSE, J., BHAT, M.N., JMMY, B., SHASTRY, B.A., Indian Journal of Critical Care Medicine, 11, no.2, 2007, p.74.

46. PLUM, L.M., RINK, L., HAASE, H.,Int. J.Environ. Res. Public. Health, 7, no. 4, 2010, p.1342, doi: 10.3390/IJ ERPH7041342.

47. AVRAM, N., SERDARU, M., MEHEDINU, C., MEDREA, N., TANASESCU, V.,The Romanian Review of Veterinary Medicine, 8, no. 2, 1998, p. 29 (in Romanian).

48. TAPALOAGA, D., MITRANESCU, D., FURNARIS, V., BUTARU, D.A., TAPALOAGA,P.R., MITRANESCU, E., The Romanian Review of Veterinary Medicine, 18, no.1, 2008, (in Romanian);

49. BALKHAIR, K.S., ASHRAF, M.A., Saudi J. Biol. Sci., 23, no. 1, 2016, p. S32, doi: 10.1016/j.sjbs.2015.09.023.

50. MOHAMED, I., AHAMADOU, B., LI, M., GONG, C., CAI, P., LIANG, W., HUANG, Q., J. Soils Sediments, 10, no. 6, 2010, p. 973, doi: 10.1007/ s11368-010-0199-1.

51. SIPOS, P., NÉMETH, T., MOHAI, I., Environ. Geochem. Health, 27, no. 1, 2005, p.1; doi: 10.1007/s10653-004-1581-y.

52. KROSSHAVN, M., STEINNES, E., VARSKOG, P., Water Air Soil Pollut.,

71, no.1-2, 1993, p.185,doi: 10.1007/BF00475520.

53. GHANI, A., IJT, 3, no.3, 2010, p. 325
54. WANG, Q.R., LIU,X.M., CUI, Y.S., DONG, Y., CHRISTIE, P., J. Environ. Sci. Health A, 37, no. 4, 2002, p. 611, doi: 10.1081/ESE-120003241. 55. KACALKOVA, L., TLUSTOS, P., SZAKOVA, J., Pol. J. Environ. Stud., 23, no. 3, 2014, p. 753.

56. ALIYU, H.G., ADAMU, H.M., ESJ , 10, no. 6, 2014, p. 30, doi: 10.19044/ esj.2014.v10n6p\%25p.

57. LU, Y., YAO, H., SHAN, D., JIANG, Y., ZHANG, S., YANG, J., J ournal of Chemistry, 2015, Article ID: 628280, doi: 10.1155/2015/628280.

58. DAI, Q., YUAN, J., FANG, W., YANG, Z., Front Biol. China, 2, no. 3, 2007, p. 303, doi:10.1007/s11515-007-0044-0.

59. TANGAHU,B.V., ABDULLAH, S.R.S., BASRI, H., IDRIS, M., ANUAR, N., MUKHLISIN, M., Int. J. Chem. Eng., 2011, Article ID: 939161, doi: 10.1155/2011/939161.

60. HOUGH, R.L., YOUNG, S.D., CROUT, N.M.J ., Soil Use Manage, 19, no. 1, 2003, p. 19, doi: 10.1111/j.1475-2743.2003.tb00275.x.

61. AKHTAR, M.J., ULLAH, S., AHMAD, I., RAUF, A., NADEEM, S.M., KHAN, M.Y., HUSSAIN,S., BULGARIU, L., Chemosphere, 190, 2017, p. 234, doi: 10.1016/j.chemosphere.2017.09.136.

62. ARSENIE, T., BULGARIU, L., Process Eng. J., 1, 2017, p. 34;

63. ARSENIE, T., NEME', L., NACU, G., BULGARIU, L., The $6^{\text {th }}$ IEEE International Conference on E-Health and Bioengineering - EHB, 2017, pp. 89-92.

64. BADESCU, I.S., BULGARIU, D., BULGARIU, L., J Appl Phycol, 29, 2017, p.1069-1079, doi:10.1007/s10811-016-0997-y;

65. NACU, G., NEGRILA, L., BULGARIU, L., Revue Roumaine de Chimie, 62, no. 4-5, 2017, p. 439.

66. NEMES, L., BULGARIU, L., Open Chemistry, 14, 2016, p. 175

Manuscript received: 14.11 .2018 